\title{
A religiosidade no enfrentamento do surto epidêmico de Zika Vírus no nordeste brasileiro
}

\author{
Fernanda Lemos* \\ Zuleica Dantas Pereira Campos**
}

\section{Resumo}

Este artigo analisa a influência da religiosidade no enfrentamento da epidemia por Zika Vírus no nordeste brasileiro, que culminou no surto de microcefalia entre famílias que já se encontravam em situação de vulnerabilidade social. Para análise dessa realidade social, apreendeu-se por meio de entrevistas, a história de vida dos sujeitos. Estes, por sua vez, tiveram suas realidades sociais radicalmente transformadas, diante da desordem social provocada pela epidemia, e por conseguinte pelo surto de microcefalia. Nesse caso, especificamente, a religiosidade apresentou-se como um elemento significativo para o enfrentamento dessa realidade, ajustando a desordem social trazida pela epidemia e pela inacessibilidade às políticas públicas. Portanto, objetiva-se compreender as implicações sociais da epidemia, bem como, a influência da religiosidade no enfrentamento dos desajustes provocados por esse evento.

Palavras-chave: Religiosidade. Epidemia. Realidade Social. Zika Vírus. Nordeste.

\section{Religiosity in coping with the epidemic outbreak of Zika Virus in the brazilian northeast}

\section{Abstract}

This paper analyzes the influence of religiosity in coping with the Zika Virus epidemic in the Brazilian Northeast, which culminated in the outbreak of microcephaly among

* UFPB. Mestre e Doutora em Ciências da Religião pelo PPGCR da Universidade Metodista de São Paulo. Docente do Departamento e do PPGCR da Universidade Federal da Paraíba, realiza, atualmente, seu estágio pós-doutoral no PPGCR da Universidade Católica de Pernambuco. E-mail: somel_ad@yahoo.com.br .

** UNICAP. Mestra em Antropologia e Doutora em História pela Universidade Federal de Pernambuco. Realizou seu estágio pós-doutoral em Ciências da Religião, pela Universidade Metodista de São Paulo. Atualmente é professora Titular da Universidade Católica de Pernambuco, atuando como coordenadora no Programa de Pós-graduação em Ciências da Religião. E-mail: zuleicape@gmail.com . 
families that were already in a situation of social vulnerability. For the analysis of this social reality, the subject's life history was captured through interviews. These, in turn, had their social realities radically transformed, in the face of the social disorder provoked by the epidemic, and consequently by the outbreak of microcephaly. In this case, specifically, religiosity was a significant element to confront this reality, adjusting the social disorder brought about by the epidemic and inaccessibility to public policies. Therefore, the objective is to understand the social implications of the epidemic, as well as the influence of religiosity in coping with the imbalances caused by this event. Keywords: Religiosity. Epidemic. Social Reality. Zika Virus. Northeast.

\section{La religiosidad en el enfrentamiento del surto epidémico de Zika Virus en el nordeste brasileño}

\section{Resumen}

Este artículo analiza la influencia de la religiosidad en el enfrentamiento de la epidemia por ZikaVirus en el nordeste brasileño, que culminó en el brote de microcefalia entre familias que ya se encontraban en situación de vulnerabilidad social. Para el análisis de esta realidad social, se aprehendió por medio de entrevistas, la historia de vida de los sujetos. Estos, a su vez, tuvieron sus realessociales radicalmente transformadas, ante el desorden social provocado por la epidemia, económicamente por el brote de microcefalia. En ese caso, específicamente, la religiosidad se presentó como un elemento significativo para el enfrentamiento de esa realidad, ajustando el desorden social trazido por la epidemia y la inaccesibilidad a las políticas públicas. Por lo tanto, se pretende comprender las implicaciones sociales de la epidemia, así como la influencia de la religiosidad en el enfrentamiento de los desajustes provocados por este evento.

Palabras clave: Religiosidad. Epidemia. Realidad Social. Zika Virus. Nordeste.

\section{Flexibilização teórica e ajustamento empírico}

Tentar definir o termo religião infere num problema epistemológico. $\mathrm{O}$ que faremos a seguir não tem a pretensão de defini-lo e muito menos encerrálo, pretendemos antes de tudo, explicar a apropriação teórico-metodológica na construção da discussão, haja vista as especificidades do campo. ${ }^{1}$ Entretanto, dada a complexidade desse construto, o termo ainda parece "carregar" o ranço da institucionalidade.

Sobre uma possível aproximação do termo religião, preferiu-se submeter à perspectiva gueertiana (2011), considerando-a como "um sistema de símbolos que atua para estabelecer poderosas, penetrantes e duradouras disposições e motivações nos homens”. (GEERTZ, 2011, p. 67). Esse sistema de símbolos, por sua vez, é capaz de significar de forma tão eficaz a realidade social, que seria capaz de proporcionar a "formulação de conceitos de uma ordem de existência geral" (IDEM). 
Se por um lado o termo religião pode nos remeter a uma ideia equivocada de institucionalidade, por outro parece desaparecer das "novas velhas" religiões que não circundam o cristianismo, considerado legítimo. Geralmente, os chamados "novos movimentos religiosos" não são nomeados como religião, mas como "movimentos", o que me parece uma tentativa do senso comum, reificado pela classificação acadêmica, de polarizar aquilo que é religião daquilo que "não o é". Religião é Religião, talvez essa seja a forma mais adequada de defini-la! Se considerarmos o substrato inerente às representações religiosas - nas mais variadas formas classificatórias, incluindo o tempo e o espaço - observaremos aproximações e distanciamentos, entretanto, o elemento sagrado como característica principal é central. Talvez o que possa diferir seja a linguagem, as particularidades dogmatizadoras e a modelagem ritualística, mas, isso não é o cerne da questão e sim as diversas formas como o sagrado se manifesta.

Diante desse constante debate, e não podendo se esquivar da necessidade classificatória acadêmica, optou-se pelo termo religiosidade, pois parece responder de forma (quase) satisfatória às demandas desse campo e sua análise. Utilizando os recursos instrumentais da língua portuguesa se poderia "adjetivar" o termo, como forma de explicar ao leitor nosso modus operandi de análise: se religião é a "coisa" em si, a religiosidade seria a qualidade daquele que a experiencia. Em termos gramaticais, a religiosidade seria, portanto, uma condição ou um estado construído pelo sujeito na constituição de sua experiência como indivíduo. Que pode estar relacionada à experiência institucionalizada, mas que também pode não depender dela e/ou exclusivamente dela.

Mesmo especificando o termo "religiosidade", nos perguntamos ainda pela individualidade "exigida" pelo sujeito moderno, considerando que sua composição religiosa é muito mais do que uma "bricolagem", uma busca sucessiva de elementos para a formação de um repertório. Seja por meio de uma busca incessante/moderada de elementos religiosos e/ou sua recepção institucionalizada e única, o indivíduo se depara com a necessidade de "digestão" dos elementos experienciados, que não perpassam sua realidade como mera colagem de símbolos sagrados. Necessário se faz o reconhecimento da capacidade indelegável do indivíduo em "digerir" e "regurgitar" o que fora experienciado, analisando assim os elementos adequados para a sua realidade, o que pode ser compreendido como um exercício de sua capacidade de ser sujeito ("sujeicidade"). Isso posto, optamos pela noção de "sujeito religioso" 
para a análise do campo, considerando que apenas eleger o termo religiosidade (como qualidade daquele que é religioso), desconsideraria o projeto individual de construção e reflexão da experiência religiosa.

Em “A Construção Social da Realidade" (2014), Berger \& Luckmann propõem uma compreensão sociológica da vida cotidiana, ao considerarem que não é tarefa fácil apreender cientificamente essa realidade. Nessa obra, os autores perguntam pela experiência para o sujeito do senso comum, uma vez que "subjetivamente [só é] dotada de sentido para eles na medida em que forma um mundo coerente" (BERGER \& LUCKMANN, 2014, p. 35). Portanto, para compreender "a realidade do senso comum temos de nos referir a estas interpretações, assim como temos de levar em conta seu caráter de suposição indubitável, mas fazemos isso colocando o que dizemos entre parênteses fenomenológicos" (BERGER \& LUCKMANN, 2014, p. 37). O desafio que se apresenta é interpretar, se possível, a realidade cotidiana a partir de seus atores, com suas variantes, instabilidades e aparente desconexão. O senso comum é um campo de informação, cabe-nos tentar interpretá-lo fenomenologicamente, sem desconsiderar sua dinâmica intersubjetiva na relação com a sociedade e os demais atores. Sendo o senso comum "um campo de informação" significativo e relevante à compreensão socioantropológica, a religiosidade seria um de seus pilares de manutenção da realidade social.

Nossa preocupação com a experiência religiosa surgiu, principalmente, entre os anos 2016 e 2017, durante a pesquisa de campo, ${ }^{2}$ quando as

2 Foram aplicados 15 questionários no Hospital Universitário da Universidade Federal da Paraíba e na Fundação Centro Integrado de Apoio ao Portador de Deficiência - FUNAD; e realizadas seis entrevistas na FUNAD entre os anos de 2016 e 2017, período de grande efervescência epidêmica e de nascimento dos casos observados na pesquisa. A escolha dos locais se deu por serem especializados no atendimento e apoio à criança com Microcefalia na capital paraibana. Sobre a situação socioeconômica das famílias entrevistadas, têm em média uma renda per capta familiar de duzentos reais, que na maioria dos casos observados é proveniente do auxílio concedido pela Previdência às crianças com microcefalia. Esse benefício é provisório, dependendo de perícias médicas constante. As mães são pardas, estão em idade reprodutiva (18 a 27 anos), têm mais de dois filhos, dedicam-se exclusivamente ao trabalho doméstico e ao cuidado infantil e possuem um nível baixo de educação formal. Todas as mães entrevistadas vivem em "união estável", nenhuma casada oficialmente. Todas tiveram o acompanhamento gestacional pelo Sistema Único de Saúde, assim com a realização do parto, que na maioria das vezes é estimulado para que seja "normal". Geralmente, são famílias que vivem em residências alugadas, mais da metade delas no meio rural, e apesar de declararem moradia em condição salubre (água encanada e rua com esgoto encanado), reconhecem que antes do nascimento do bebê com 
consequências sociais de um surto epidêmico iniciado em 2015 começaram a se descortinar no nordeste brasileiro. O Zika Vírus (ZIKV) - até então desconhecido por aqui, mas, detectado na África em meados do século passado - trouxe consigo implicações drásticas para a realidade dos brasileiros, principalmente dos nordestinos. A infecção por Zika Vírus fora num primeiro momento tratada como uma "virose", dado o desconhecimento médicocientífico de sua existência e posteriormente, descobriu-se que "essa virose" era decorrente da picada do mosquito Aedes Aegypti. Entre outras doenças, a picada do mosquito era responsável por outras duas doenças com sintomas muito parecidos: a Dengue e a Chikungunya.

Segundo os dados do Ministério da Saúde, milhares de brasileiros foram afetados por doenças decorrentes da picada do mosquito que, entre outros sintomas, acometia o infectado de febre alta, de manchas e dores intensas pelo corpo. Mas nenhum desses sintomas fora tão impactante quanto os causados pelo ZIKV, visto que além das implicações individuais trouxe danos irreversíveis à sociedade. Após sua devastadora aparição nos corpos nordestinos, observou-se o nascimento significativo de crianças com microcefalia, com especificidades diferentes do padrão da doença. Gestantes que procuravam o serviço público de saúde, tanto na Paraíba quanto em Pernambuco, e tinham seus bebês diagnosticados com microcefalia, relatavam que tinham tido febre e manchas no corpo no segundo e terceiro mês de gravidez. Começava-se a desvendar, de forma muito peculiar, as consequências congênitas do ZIKV no cotidiano das famílias nordestinas.

Inicialmente, suspeitamos que os sujeitos afetados pela epidemia possuíam uma religiosidade catolicamente institucionalizada. Visto que um número considerável de indivíduos residia no sertão, local onde o catolicismo, além de configurar a religião comum, ainda representa um espaço comunitário e de sociabilidade. Entretanto, os sujeitos apresentaram outra configuração religiosa, que consideraremos durante as discussões. Isso posto, diante do fenômeno e de suas características teratogênicas, buscaremos compreender panoramicamente a história da epidemia, bem como, suas consequências para a realidade social. Num segundo momento, analisaremos o construto

microcefalia viviam próximo a mangues, esgoto a "céu aberto" e próximo de matas. Fato esse que favorece o aparecimento do mosquito hospedeiro da Zika, logo, um dos motivos pelos quais não encontramos no campo pesquisado, ainda, famílias consideradas de classe média e alta. Talvez a associação da epidemia a péssimas condições de saneamento básico responda à problemática sobre os motivos pelos quais a síndrome congênita pelo ZIKV tenha sua classe social muito bem definida. 
religiosidade e, por fim, por meio da história de vida dos sujeitos impactados pelo surto, observaremos a contribuição da religiosidade na ressignificação de suas realidades frente a situações de precariedade social e desajustes biográficos. Estamos nos perguntando, fundamentalmente, pela importância do construto religiosidade no enfrentamento de realidades sociais precárias. Suspeitamos que a religião, e seu arcabouço simbólico, explique os dramas sociais de forma tão eficaz, bem como, suas incongruências, que seja legitimadora da realidade social (BERGER, 1985).

\section{A realidade social da epidemia}

Aparentemente, questões de saúde têm pouco ou nada a ver com o campo social. No caso das epidemias, apresentam um status supremo de causalidade biológica, natural e que diz respeito ao mundo exclusivo das ciências médicas. Entretanto, o contexto epidêmico exibe aspectos intrínsecos à realidade social, isso porque "a prevalência e distribuição da doença - quaisquer que sejam suas causas biológicas próximas - são socialmente articuladas” (STARK, 2004, p. 9). Não se nega com isso que há um elemento natural da doença, mas, o que Stark (2004) observa é um processo de "transição da determinação natural para a social", uma transição da "causação natural à causação social" da doença. No caso das epidemias, a articulação social é marcadamente relevante, uma vez que envolve um número significativo de sujeitos que são afetados pela mesma doença e no mesmo período histórico, como bem observa Foucault, em "O Nascimento da Clínica":

A análise de uma epidemia não se impõe como tarefa reconhecer a forma geral da doença, situando-a no espaço abstrato da nosologia, mas reencontrar, sob os signos gerais, o processo singular, variável segundo as circunstâncias, de uma epidemia a outra que, da causa à forma mórbida, tece em todos os doentes uma trama comum, mas singular, em um momento do tempo e em determinado lugar do espaço (FOUCAULT, 1977, p. 26).

A característica principal da epidemia não é, exclusivamente, a doença individual, mas, sua manifestação coletiva geográfica e culturalmente localizada. Entretanto, "tem uma espécie de individualidade histórica" (FOUCAULT, 1977, p. 27). O que faz que Evan Stark $(2004,6)$ considere a epidemia como um fato social, visto que ocorre em meio às transformações da sociedade, e diríamos mais, como agenciadora de mudanças sociais. Segundo Rita de Cassia Barradas Barata (1987, p. 9), “as epidemias estiveram 
sempre presentes na história do homem na Terra, intensificando-se nas épocas de transição entre os modos de produção e nos momentos de crise social". A autora discute os relatos de epidemias durante a Antiguidade e a Idade Média, mas, destaca a "Peste Negra" - por seu caráter devastador entre a população europeia, trazendo para a análise a distinção fundamental entre epidemia e doença: "a doença sempre se repete, enquanto a epidemia, nesse sentido, é única. O que faz da epidemia um fato único é a especificidade do contexto no qual ela ocorre e não a essência da doença em questão" (BARATA, 1987, p. 9).

A história social das doenças demonstra que surtos epidêmicos foram responsáveis pela devastação de grandes cidades, impactando significativamente sociedades e culturas. A título de exemplo, podemos citar o surto de cólera-morbo ocorrido no Brasil no final do século XIX, responsável pela morte massiva de milhares de pessoas no nordeste brasileiro, em virtude da entrada de europeus pelo litoral. $\mathrm{Na}$ ocasião, uma série de leis higienistas surgiram para tentar frear a epidemia que se espalhava rapidamente, o que implicou na criação de espaços para enterrar os mortos (cemitérios). Dois séculos depois, epidemias como a febre amarela, dengue, malária aparecem como resultado de discrepâncias sociais no "mundo moderno", quando a falácia do controle epidêmico e da acessibilidade populacional às políticas públicas não é realidade. As epidemias são, portanto, resultado de questões sociais historicamente localizadas. No caso de nossa pesquisa, especificamente, lidou com dois problemas: o primeiro deles se refere à epidemia de doenças específicas como Dengue, Chikungunya e Zika; e o segundo, com o surto de microcefalia decorrente do Zika, que marcadamente centrou-se na região nordeste do Brasil.

Como já mencionado, em 2015 o Nordeste foi assolado com casos de Zika, uma doença até então pouco conhecida pela comunidade médica e pela população dessa região. Geralmente, os indivíduos acometidos por Zika residiam em lugares com pouco ou nenhum saneamento básico, o que facilitava a proliferação do mosquito. As dores no corpo, a febre alta e as manchas vermelhas no corpo de quem era acometido pela doença passavam em três dias, e o tratamento consistia em ingestão abundante de água e repouso absoluto. Entretanto, para um número significativo de famílias afetadas pela doença os sintomas não desapareceram em três dias, ao contrário, marcariam definitivamente suas biografias. Após o grande surto epidêmico, médicos neonatologistas da Paraíba e de Pernambuco começaram 
a perceber, em seus consultórios, um número incomum de gestantes que procuravam o Sistema Único de Saúde com fetos apresentando problemas congênitos específicos. Os exames ecográficos evidenciavam fetos com microcefalia, entretanto, com características incomuns para os padrões da doença - a calcificação do cérebro era diferente das já observadas e relatadas na literatura médica. A recorrência desse padrão nos consultórios, especificamente naquela região e período preocupou os médicos, levandoos ao questionamento sobre essa nova forma de apresentação da doença. A Dra. Adriana, em constante diálogo com os colegas nordestinos, começou a indagar acerca da história de vida das mulheres durante a gestação. Durante a anamnese, observou que todas as gestantes, com fetos que apresentavam a malformação congênita, haviam sido infectadas por ZIKV nos primeiros meses de gestação.

A percepção da associação entre a infecção por ZIKV durante a gestação e a microcefalia começava a surgir, quando exames com o líquido amniótico das gestantes confirmou as suspeitas da Dra. Adriana (DINIZ, 2016). Até então o Ministério da Saúde, que não dera tanta importância às suspeitas, passou a emitir boletins epidemiológicos:

\section{Casos de Microcefalia e/ou malformações, sugestivos de infecção congênita, notificados pelo Ministério da Saúde até 30/04/2016}

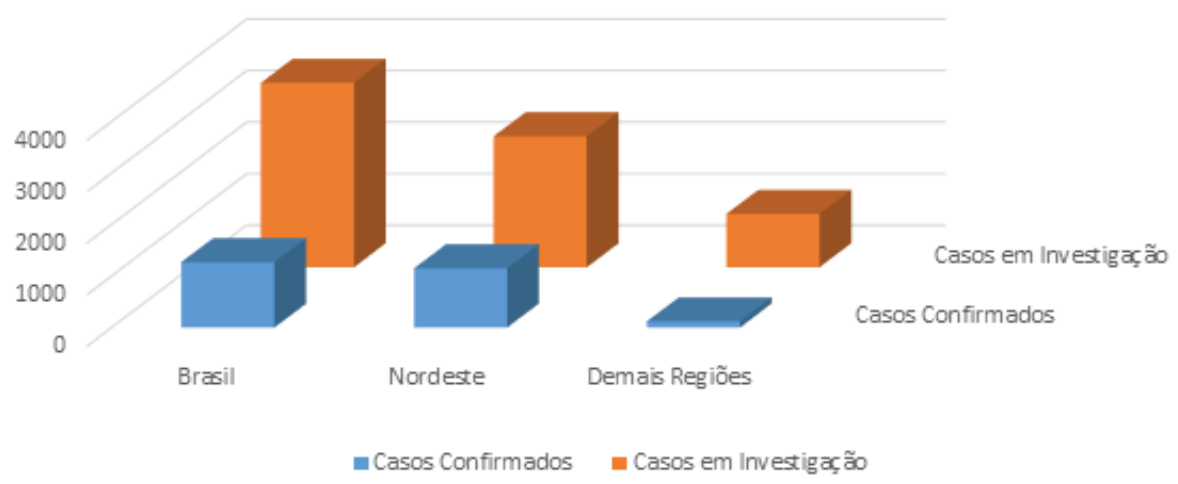

O Ministério da Saúde do Brasil passou a nomear a microcefalia associada ao ZIKV como: "microcefalia e/ou malformações, sugestivos de infecção congênita”, uma vez que não era só a microcefalia que a infecção pelo vírus trazia aos bebês, mas uma série de implicações motoras, sensoriais 
e neurológicas. Para se ter ideia da dimensão epidemiológica, até abril de 2016, segundo dados informados pelo Ministério da Saúde, o Brasil possuía 3.580 casos em investigação e 1.271 confirmados. Significativamente, o Nordeste representava 2.544 casos em investigação e 1.152 confirmados, perfazendo um total de $91 \%$ da realidade brasileira. ${ }^{3}$

Desde que houvera a suspeita de "infecção congênita por ZIKV", instaurou-se um problema de abrangência nacional, com consequências gravíssimas às gestantes e suas famílias. Entretanto, a situação foi mais grave na região nordeste do país que, como já mencionado, no início da epidemia concentrou cerca de $91 \%$ dos casos confirmados da doença. A epidemia tem classe social, gênero e está geograficamente concentrada, isso porque atinge significativamente famílias empobrecidas e nordestinas. Debora Diniz, uma das primeiras pesquisadoras do tema, relatou essa realidade em livro, resultado de sua atuação durante o surto, intitulado: "Zika, do sertão nordestino à ameaça global", nele descreve a "angústia das mulheres grávidas e cuidadoras de seus filhos recém-nascidos sobre o desconhecido da doença" (DINIZ, 2016, p. 7).

Residentes no Nordeste, também observamos de perto a precariedade enfrentada pelas famílias atingidas pelo surto epidêmico. Acompanhou-se, in loco, a situação de vulnerabilidade e a falta de saneamento básico adequado o que favorece a multiplicação do mosquito - e a dependência de programas governamentais como fonte primeira de recursos financeiros. Diante disso, o nascimento de um novo membro familiar com sérias limitações neuro e psicomotoras demanda dedicação exclusiva e gastos diferenciados, apesar do singelo apoio governamental. Geralmente, são sujeitos de áreas rurais, com recursos básicos negligenciados pelo Estado, homens e mulheres que tiveram suas rotinas transformadas por um evento que não será passageiro, entretanto, deparamo-nos com sujeitos que acreditavam numa melhora significativa de seu bebê e até na cura divina. Fato similar também fora observado por Diniz (2016, p. 18): “com algumas mulheres no grupo de Whats App aprendi que, além do zika, a criança sofria de quebranto, e por isso era importante ir à estimulação precoce e também às rezadeiras", e por nós, quando uma de nossas entrevistadas declara ter tido um bebê com a síndrome congênita pelo ZIKV em virtude do resgate de vidas passadas.

\footnotetext{
Para informações mais bem detalhadas consultar: Portal Brasil, com informações do Ministério da Saúde. http://www.brasil.gov.br/saude/2016/05/microcefalia-ministerioda-saude-confirma-1-271-casos-no-pais. Extraído em: 07/05/16.
} 
Desde o diagnóstico intrauterino, até o nascimento da criança com microcefalia, há uma sucessão repentina e desenfreada de episódios dramáticos que afetam o grupo familiar, mas principalmente as mães, o que representa uma série de implicações biopsicossociais para a mulher. Diante desse percalço na trajetória biográfica das mães, há que se buscar sentido para a realidade social precária que se apresenta, que suspeitamos ainda ser antecedida pela escassez de recursos básicos à sobrevivência. Diante dessa realidade social precária, a religião - entendida aqui não exclusivamente por sua dimensão institucionalizada - pode contribuir para o ajuste social dos sujeitos envolvidos nessa problemática. Ou seja, é provável que entre as mães que enfrentam essa precária e fortuita experiência, surjam aquelas que encontrem nas legitimações religiosas explicações para significar suas realidades, haja vista que "a religião serve, assim, para manter a realidade daquele mundo socialmente construído no qual os homens existem nas suas vidas cotidianas" (BERGER, 1985, p. 41).

\section{A religiosidade e o enfrentamento social}

Berger (2017, p. 9) apresenta uma "possibilidade", nomeada por ele de "indutiva", para compreender e interpretar a religião "nos termos da secularidade moderna". ${ }^{4}$ Segundo ele, tal tipologia contribuiria à compreensão da experiência como:

Fundamento de todas as afirmações religiosas - a própria experiência, até onde isso for possível, e a experiência corporificada num conjunto particular de tradições. Esse conjunto pode ser de amplitude variada - minimamente limitada a nossa própria tradição ou maximamente expandida para incluir todo acervo disponível da história religiosa humana (BERGER, 2017, p. 84-85).

\footnotetext{
4 Em seu livro "O Imperativo Herético", Berger (2017) delineia o que nomeia de construtos intelectuais como ferramenta metodológica para a compreensão da condição contemporânea da religião na modernidade. Sem a pretensão de estabelecer categorias analíticas absolutas o autor demonstra, assim como Hervieu-Léger (2008), possibilidades de existência da religião na modernidade. Entre os aspectos destacados por ele, se exibem três opções de interpretação da religião na modernidade: a dedutiva, a redutiva e a indutiva. A primeira se apresentaria como alternativa para a reafirmação da autoridade tradicional da religião na modernidade; enquanto que a segunda utilizaria a releitura/reinterpretação de elementos tradicionais para a formulação de seu postulado "nos termos da secularidade moderna"; já a terceira via trazida pelo autor, e que parece condizer com a realidade de nosso campo, colocaria a experiência como fundamento da religiosidade contemporânea.
} 
A opção indutiva seria uma ferramenta de análise para a compreensão da relação religião e modernidade. Ela, por sua vez, não teria a capacidade de revelar a experiência em si, mas poderia ao menos contribuir para tipificá-la, nos dando a conhecer possibilidades analíticas de objetificação do campo religioso na contemporaneidade. Para o autor, seria "uma atitude deliberadamente empírica", descompromissada da autoridade religiosa em sua legitimidade, o que a tornaria como opção única no "enfrentamento e superação dos desafios postos pela situação moderna” (BERGER, 2017, p. 85). Nesse sentido, o autor não teria a pretensão de eleger a modernidade como a nova ordem de autoridade sobre o religioso - mesmo porque a opção indutiva pode culminar em um reducionismo, quando "alternativamente, suas frustrações levam a uma rendição das velhas certezas" (BERGER, 2017, p. 87). Seria, mais objetivamente, a "mudança da autoridade para a experiência como foco do pensamento religioso" (BERGER, 2017, p. 87).

O Autor propõe mais que categorias tipológicas estagnadas para instrumentalização e análise da religião, sugere "tomar a experiência humana como ponto de partida da reflexão religiosa, e recorrer aos métodos do historiador para descobrir aquelas experiências humanas encarnadas nas várias tradições religiosas" (BERGER, 2017, p. 154). Não significa com isso que o sujeito religioso contemporâneo seja fruto de um "imperativo herético" da modernidade, mas que nem sempre suas experiências são exclusivamente pautadas pela tradição institucionalizada e/ou pela releitura da tradição. Em defesa de seu "tipo ideal", Berger (2017, p. 10) considera que a "abordagem indutiva oferece novas oportunidades para compreender o fenômeno religioso de modo transcultural e abrangente". Isso posto, a variedade de experiências cotidianas pode condicionar e/ou ser influenciada pela experiência religiosa, isso porque a biografia do sujeito é construída de elementos sociais que podem conter a dimensão religiosa (ou não). No caso de nossa pesquisa de campo, a religiosidade é inerente à biografia.

Com o nascimento de centenas e até milhares de crianças portadoras de microcefalia no Nordeste, a realidade das famílias foi drasticamente transformada pelo surto epidêmico. Os sujeitos sociais tiveram que enfrentar uma realidade social drástica e caótica: o cuidado de um novo integrante do grupo familiar com uma série de necessidades especiais, como uma equipe médica multidisciplinar e precoce estimulação para o desatrofiamento corporal. Diante de tal situação - tanto da falta de informação/conhecimento (de médicos, de cientistas e de pacientes) da nova doença que se apresentara 
quanto das dificuldades enfrentadas pela frustração na chegada de um novo membro familiar com limitações específicas - os sujeitos recorreram à sua religiosidade. Talvez essa busca se mostre como necessidade ao enfrentamento dessa realidade social, na explicação de fatos que nem mesmo "a ciência" conseguira esclarecer naquele momento.

Não há um padrão para as limitações que essa enfermidade pode causar nos bebês, entretanto, seu caráter teratogênico é um fato. Observamos crianças, in loco e por meio dos prontuários, que desde os primeiros meses de vida participam da "estimulação precoce", e após três anos de tratamento ainda não falam, não enxergam e não ouvem. Outras, porém, conseguem dar passos com o apoio das fisioterapeutas e mães. Segundo especialistas, tudo depende do grau de calcificação do cérebro durante seu desenvolvimento gestacional. Das famílias entrevistadas na Fundação Centro Integrado de Apoio ao Portador de Deficiência - FUNAD, a maioria residia no sertão e dependia do transporte municipal para semanalmente levarem seus filhos à estimulação na FUNAD. Por diversas vezes os pais não compareceram à entrevista, apesar do atendimento na Fundação estar previamente agendado, pois as prefeituras não disponibilizavam seus carros para transporte das crianças à Fundação.

Todas as mães entrevistadas dedicam-se exclusivamente ao trabalho doméstico, principalmente no cuidado integral da criança com a deficiência congênita. Sobre suas religiosidades, todas se declaram católicas, mas afirmam não frequentar a missa. Alegam que as crianças exigem muito cuidado, além dos filhos que já possuem, logo, a ida à igreja seria conturbada. Suspeitamos também que essa não ida esteja condicionada ao estigma social, visto que em regiões interioranas do sertão nordestino a missa ainda constitui um espaço de socialização. Le Breton (2011, p. 73) considera que "nossas sociedades ocidentais fazem da 'deficiência' um estigma, quer dizer, um motivo sutil de avaliação negativa da pessoa", em outras palavras, o autor demonstra a ambivalência presente no corpo deficiente, ele serviria como evidência da distinção social, revelando à sociedade não uma condição, mas uma essência!

No caso da microcefalia, a doença se evidencia imediatamente no corpo, visto que a cabeça do bebê é significativamente pequena, além do atrofiamento de pés, pernas e mãos. É um corpo enrijecido, que comunica a malformação cerebral, mas antes de tudo a incompletude da maternidade e da bênção divina. A ida à missa dominical, além de laboriosa - pela condição da 
criança - também revelaria o estigma social ${ }^{5}$ da doença perante a comunidade, como afirma a Mãe de Jasmim: como se ela fosse um bicho de sete cabeças. Segundo ela, até hoje sente o preconceito das pessoas olhando sua criança.

Em perspectiva religiosa, o perfil das mães, considerando o aspecto geográfico do fenômeno observado, demonstrou uma hegemonia católica. Como já mencionado, além de todas se declararem católicas, também foram batizadas na religião declarada. Quando questionadas sobre a possibilidade de batismo da criança com microcefalia:

\section{Batismo da Criança com a Síndrome}

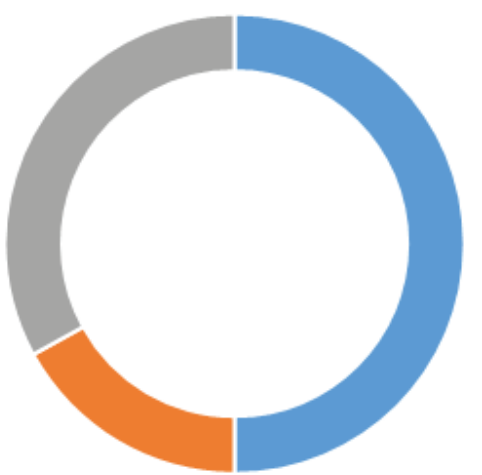

- Batizado no Catolicimo " Ainda não batizado, mas será no catolicismo " Não declara am

No que se refere à herança religiosa do nordestino, há possibilidade de perpetuação do catolicismo, mesmo com a prática não institucionalizada; como se a tradição católica, e mesmo que dissolvida nos entremeios da modernidade, ainda significasse a base referencial (não exclusiva) de fé. As mães que afirmaram "ainda não" terem batizado suas crianças, declararam que será no catolicismo. Quando questionadas sobre a frequência na religião declarada, quase $70 \%$ delas não participam das missas e o restante delas raramente o fazem. Fato que pode ter como motivador, como já mencionado, o estigma social da doença. Fato é que a impraticabilidade da crença no âmbito católico não impede que os elementos dogmáticos desse universo contribuam às legitimações religiosas. O que Berger (2017) nomeou de "minitradições" compõe o universo simbólico das mães, que são formas de

5 A característica sociológica mais significativa do estigma, segundo Goffman (1980), é a distinção entre a anormalidade e a normalidade. Ou seja, se por um lado o estigma deprecia um indivíduo, por outro, ele afirma a normalidade de outrem. 
pensamento religioso apreendidas durante a constituição social biográfica dos sujeitos, que podem ser acessados a qualquer momento, mesmo que concomitante a outras experiências religiosas, como podemos constatar a seguir, no que se refere à crença relacionada ao surto epidêmico:

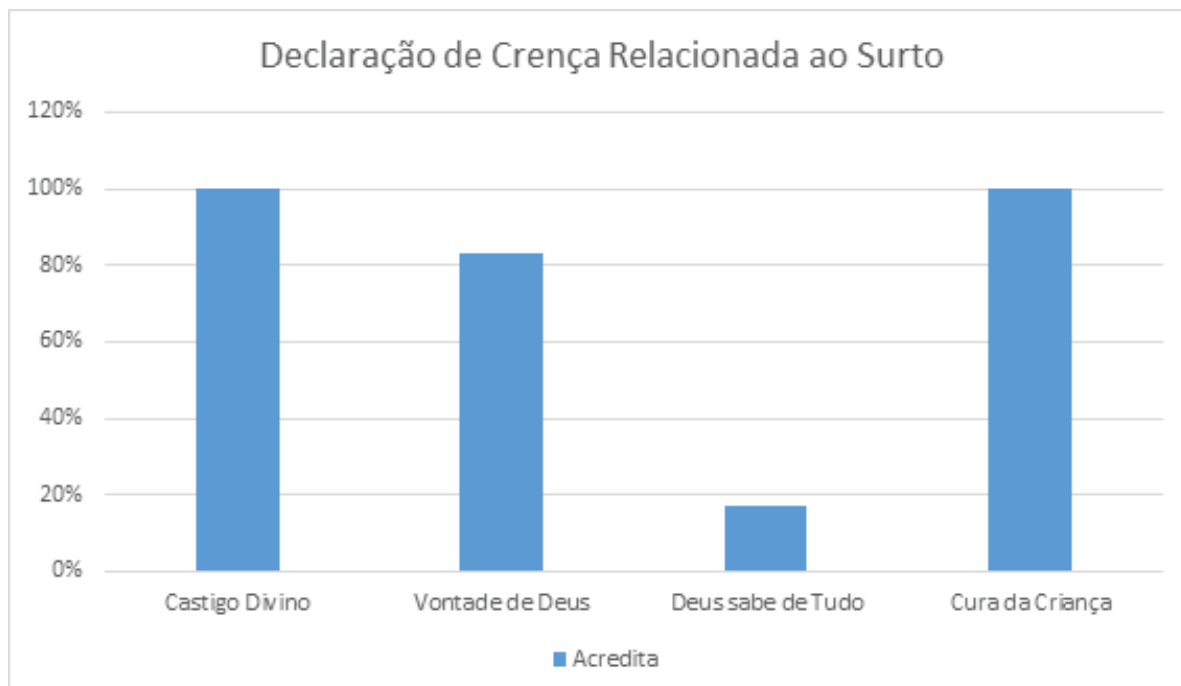

Apesar do catolicismo "não praticante" das mães, nota-se que temas fortemente acentuados nesse contexto religioso estão presentes no cotidiano delas, contribuindo assim para legitimar suas expectativas frente à enfermidade de seus filhos. Todas as entrevistadas creem no "castigo divino", o que nesse contexto específico pode representar a tentativa de compreensão do fenômeno experienciado. Tanto os atributos exigidos das mães para o cuidado infantil quanto a incerteza da síndrome pouco conhecida as levaram ao questionamento dos motivos da doença. Como já mencionado, pouco se sabia sobre a síndrome, não havia entendimento médico, científico e das mães acerca do acometimento dessa doença em seus bebês. A única coisa que se suspeitava era da correlação entre a infecção por Zika durante a gestação e a microcefalia. Nada mais se falava às mães, mesmo porque a comunidade científica e médica ainda não tinha resposta alguma, havia um abismo informativo para essas famílias, não por culpa médica, mas pelo ineditismo do surto epidêmico.

É certo que o substrato da crença já era presente socioculturalmente na mentalidade coletiva e individual dessas mães, entretanto, a dúvida e a falta de explicação imediata ao problema que se instalava naquele momento 
reforçou os elementos religiosos - dado o imediatismo que a circunstância exigia. Acessou-se um referencial já existente, com o objetivo de dar significado ao que ainda não tinha sentido. Apesar de nenhuma experiência com a área das ciências médicas, acabamos nos familiarizando com os termos que circundavam esse universo. Durante a análise dos "discursos" da equipe multidisciplinar de saúde, observamos o abismo que separava a medicina de seus doentes. Algo nos chamou atenção durante as entrevistas, a insistente argumentação das mulheres de que só tiveram a notícia da microcefalia com a chegada do bebê e/ou um mês antes de seu nascimento. Confrontando tal informação com os prontuários, trazidos também da maternidade com todo o histórico da gestação e do desenvolvimento da criança, observamos que os profissionais responsáveis pela ecografia descreviam nos exames: “a mãe foi informada, em linguagem do senso comum, sobre as imagens ecográficas no qual o perímetro cefálico do feto é inferior ao padrão para o período gestacional". Entrevistando um dos médicos da neonatologia que assinava alguns dos prontuários analisados, ele nos esclareceu que a falta de cognoscibilidade das mães dificultava o entendimento da real situação da criança. Fato contestado por uma das assistentes sociais que atendem às mães e que considera a linguagem médica incapaz de informar famílias, que têm pouca ou nenhuma educação formal, sobre a situação real do diagnóstico.

Ou seja, a novidade do surto epidêmico, associado à incognoscibilidade das mães e à inteligível e impaciente linguagem médica tornaram-se "monstros" no cotidiano dos sujeitos. Enquanto que tais fatores foram inteligíveis à compreensão do senso comum, o imaginário religioso presente nesse universo fora capaz de informar de forma muito mais clara e significativa as incongruências da realidade social. Informações do tipo: "Deus castiga", "tudo é vontade de Deus", ou "Deus sabe de todas as coisas", se tornaram, obviamente, explicações mais simples e objetiva para problemas tão dramáticos da biografia. As crenças tornaram-se mais acessíveis à plausibilidade de uma realidade social dramática.

No caso da "Síndrome Congênita por Zika Vírus", o caráter teratogênico é definitivo, apesar da "estimulação precoce" contribuir para a evolução da criança, não há possibilidade de cura, visto que os danos causados ao cérebro são irreversíveis. Entretanto, todas as mães acreditam na cura de seus filhos, algumas relatam ainda que "veem" futuramente seus filhos correndo por todo canto, mesmo porque creem que todas as coisas têm permissividade divina, até mesmo questões sociais. Uma das mães (MJ) afirma: 
"Deus fez isto para provar que somos capaz de enfrentar várias coisas. Apesar de Deus não ter nada a ver com isso, a religião ajuda a gente a enfrentar e passar por isso". Da mesma forma, uma terceira entrevistada (ML), considera que "Deus fez isto para provar que somos capaz de cuidar dele e conhecer os limites da gente". A religiosidade emana, apesar da não praticabilidade religiosa institucional do sujeito, da necessidade do enfrentamento da realidade social. Os símbolos religiosos, mesmo que recônditos, são acessados e aplicados. Também, podem ser buscados em outros sistemas religiosos. Outra mãe (MF) declara ser católica, batizada, e apesar de não frequentar religião alguma atualmente batizou sua filha no catolicismo, mas admite tê-la levado ao "benzedor", pois busca um milagre.

A religião acaba preenchendo aquela lacuna que outros sistemas de informação não alcançam. Ela é mais acessível do que outros recursos, até mesmo material, nesse sentido a constituição da religiosidade torna-se um processo biográfico, de acordo com cada trajetória individual. Apesar de todas as mães serem declaradamente católicas e batizadas, o universo católico é apenas um dos componentes da religiosidade por elas constituído, é uma das escolhas! No conjunto de perguntas relativas à religiosidade, perguntamos às mães no que acreditavam:

\section{Você Acredita em...}

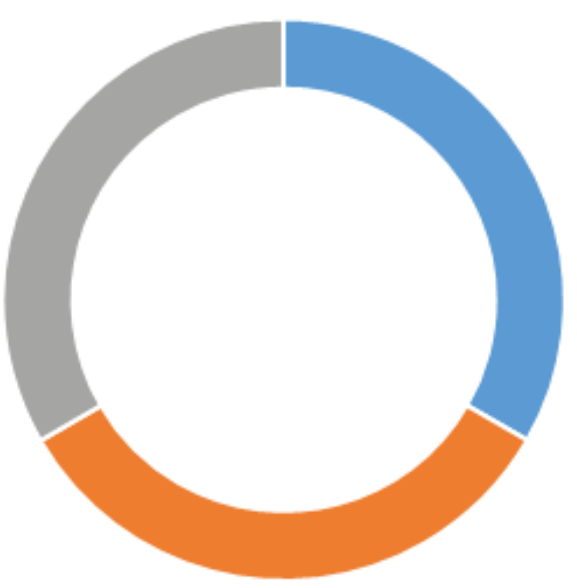

- TUDO (mas Deus em primeiro lugar) - DEUS = MILAGRE (em relação à doença) 
Enquanto algumas entrevistadas respondiam acreditar em "Deus" ou em "tudo", quando indagadas sobre "no que acreditavam", uma das mães (MF) de imediato nos informa: "eu queria um milagre, mas não aconteceu até hoje". Essa mãe não frequenta atualmente qualquer religião, mas acredita que Deus pode curar sua filha, entretanto, confessa que já pensou que as limitações da criança poderiam estar ligadas ao castigo divino, castigo esse que está "atrelado a dívidas de vidas passadas que temos que pagar em algum momento", referindo-se à reencarnação (ela não usa esse termo).

Dada a referência basilar que os sujeitos receberam no catolicismo, observa-se a personificação da divindade na resposta de $33 \%$ das entrevistadas, mas também há a declaração de crença "em tudo" na mesma proporção. O que evidencia uma religiosidade composta pela religião herdada, mas também por buscas em outros universos simbólicos, como já discutido. A religião declarada não fora descartada, mas, coadunada, o que indica que a experiência religiosa herdada não exclui as experienciadas em outras. Por sua vez, a resposta imediata ao "milagre" foi um dos elementos que nos chamaram a atenção, pois, demonstrou a importância da religiosidade durante o enfrentamento dessa situação social. O sagrado tem sua importância na vida das mães, mas tem mais utilidade quando servir para o enfrentamento da realidade de uma maternidade em situação de sofrimento. Ou seja, a busca pela cura não está dissociada da busca pela divindade, mesmo porque ela pode ter se intensificado nesse exato momento biográfico.

\section{Considerações finais}

A religiosidade, entendida nessa discussão como parte constitutiva da experiência social do sujeito, tem características próprias e inconclusivas, o que torna inefável a tarefa do cientista social da religião. No caso da análise de um fenômeno no campo da saúde, que aparentemente não tem nada ou pouco a ver com os estudos de religião, exige-se perspectivas multidisciplinares, o que não configura problema algum para as Ciências das Religiões. Portanto, o fato de o problema estar localizado "no lugar" das ciências médicas não impede que as análises se deem pelo viés socioantropológico da religião, quando o fenômeno do surto é acessado e analisado a partir da religiosidade dos sujeitos.

Assim como compreender o "senso comum", como um universo que informa a realidade social, apreender a composição religiosa do sujeito moderno também é um desafio que se impõe. A aparente incompatibilidade simbólico-religiosa apresentada na demonstração de sua religiosidade só se 
torna confusa na lógica classificatória do cientista da religião, porque para o sujeito religioso é clara e faz o sentido necessário ao enfrentamento da realidade que se impõe. Daí a necessidade de uma flexibilização teórica para o ajustamento empírico, durante o processo etnográfico: não são mais as "supremas teorias" que analisam o campo de pesquisa, mas a dinâmica observada no campo que contribui para reformulação de "velhas certezas". O campo apresenta novas/outras realidades, que nem sempre são entendidas pelas "clássicas teorias acadêmicas". Por isso, nossa compreensão para além da "religiosidade coisificada" buscou compreender o sujeito religioso moderno a partir de sua experiência religiosa individualizada, que por sua vez não é desprovida de processos coletivos.

O surto epidêmico se manifestou como o motivo pelo qual Deus "que sabe de todas as coisas" - impugnaria nos sujeitos religiosos sua (des) graça. Diante de realidades socialmente estabelecidas, homens e mulheres creem que a dificuldade que enfrentavam naquele momento (doença do filho) era determinação divina, por isso, assumiram como "missionários" a laboriosa tarefa de cuidar de uma criança com severas limitações físicas, motoras e neurológicas. A religiosidade nesse contexto, principalmente no sertão nordestino, é tão vital quanto os procedimentos médicos. Enquanto a medicina informa às famílias a impossibilidade de recuperação integral das condições motora, física e neurológica... a religião concede a expectativa da "certeza" divina da cura e do milagre. Não basta só explicar os motivos pelos quais o filho fora acometido com essa malformação congênita e prometer melhoras no quadro, é necessário - como faz a religião - explicar o inexplicável e dar esperança de um futuro sem a doença. Nesse caso, só a religião é capaz de alterar drasticamente o quadro sentenciado da doença, que é irreversível. E não importa de onde os elementos religiosos venham, ele é buscado/acessado tanto na diversidade oferecida pelo mercado religioso, quanto pelas antigas memórias dos sujeitos ("minitradições").

A religião tanto informa o motivo pelo qual a doença se instalou na família como fornece condições para o enfrentamento das dificuldades vindouras. Em geral, a composição da religiosidade dos sujeitos entrevistados demonstra uma significativa influência do catolicismo, o que confirma os dados censitários sobre essa religião na região nordeste e em áreas onde o processo de urbanização ainda não é completo. Apesar da declaração de não frequência às atividades religiosas, evidencia-se também a intenção da propagação desses símbolos às futuras gerações, dada a importância 
empenhada no batismo dos filhos. De igual modo, as "minitradições" (BERGER, 2017) são acessadas com veemência, bem como, outros recursos religiosos buscados, na tentativa de amenizar o drama biográfico e familiar.

O elemento religioso assumiu diferentes perspectivas no processo do surto. Num primeiro momento, contribuiu como acesso imediato ao problema que não tinha nem solução nem explicação, tanto pela sociedade quanto pela comunidade médico-científica. Num segundo momento, proporcionou aos sujeitos a elaboração de legitimações religiosas para compreender aquele episódio biográfico específico. E, por fim, trouxe perspectiva de enfrentamento da realidade para o futuro. Dito de outra forma, a religião contribuiu para que os sujeitos sociais a) aceitassem um problema, até aquele momento, inexplicável; b) que explicassem, em termos de legitimação religiosa, o drama biográfico e coletivo experienciado; e por fim, c) que acreditassem na possibilidade de cura, mesmo nesse contexto irreversível da doença.

Buscou-se, a partir da experiência religiosa, compreender como o sujeito enfrenta esse drama social. ${ }^{6}$ Evidenciou-se, nesse caso específico, que a religiosidade é inerente à biografia dos sujeitos e os símbolos do catolicismo acessados no cotidiano, concomitante a outros elementos religiosos. A linguagem religiosa - ao contrário da linguagem técnico-científica das ciências médicas - apresentou-se como possibilidade interpretativa do problema enfrentado.

\section{Referências}

BARATA, R. C. B. Epidemias. Cadernos de Saúde Pública. Ano 3, n. 1, p. 9-15, jan./fev. 1987.

BERGER, Peter L. O Dossel Sagrado: elementos para uma teoria sociológica da religião, 3. ed. Trad. José Carlos Barcellos. São Paulo: Paulus, 1985.

BERGER, Peter L. O Imperativo Herético: possibilidades contemporâneas da afirmação religiosa. Trad. Flávio Gordon. Petrópolis: Vozes, 2017.

BERGER, Peter L. \& LUCKMANN, Thomas. A Construção Social da Realidade, 36. ed. Trad. Floriano de Souza Fernandes. Petrópolis: Vozes, 2014.

O surto de microcefalia poderia ter sua dimensão exclusivamente natural, se não fosse a forma como se originou, se desenvolveu socialmente e afetou determinada região que, não por acaso, possui um elevado grau de empobrecimento e esquecimento governamental (no caso das políticas públicas). 
DINIZ, Debora. Zika: do sertão nordestino à ameaça global. Rio de Janeiro: Civilização Brasileira, 2016.

FOUCAUlT, Michel. O Nascimento da Clínica. Trad. Roberto Machado. Rio de Janeiro: Forense-Universitária, 1977.

GIDDENS, Anthony. As Consequências da Modernidade. São Paulo: Unesp, 1991.

GIDDENS, Anthony. Modernidade e Identidade. Rio de Janeiro: Zahar, 2002.

GOFFMAN, E. Estigma: notas sobre a manipulação da identidade deteriorada, 3. ed. Rio de Janeiro: Zahar Editores, 1980.

HERVIEU-LÉGER, Daniele. O Peregrino e o Convertido: a religião em movimento. Petrópolis: Vozes, 2008.

LE BRETON, David. A Sociologia do Corpo, 5. ed. Trad. Sonia M.S. Fuhrmann. Petrópolis: Vozes, 2011.

MINISTÉRIO DA SAÚDE. Portal Brasil: com informações do Ministério da Saúde. http:// www.brasil.gov.br/saude/2016/05/microcefalia-ministerio-da-saude-confirma-1-271-casosno-pais. Extraído em: 07/05/16.

STARK, Evan. A Epidemia como Fato Social. Trad. Carlos Roberto Oliveira. Rio de Janeiro, 2004. (Originalmente publicado no: International Journal of Health Services, v. 7, n. 4, 1977, p. 681-705, Baywood Publishing Co., Inc.)TEIXEIRA, Faustino \& MENEZES, Renata. As Religiões no Brasil: continuidades e rupturas. Petrópolis: Vozes, 2011.

Submetido em: 15-11-2018

Aceito em: 11-4-2019 